\title{
New business models for Cultural and Creative Institutions
}

Sławomir Nikiel, Ph.D., D.Sc., University of Zielona Góra, Faculty of Economics and Management, Poland ORCID: 0000-0003-3648-6359.

\section{Introduction}

CCII (Cultural and Creative Industries and Institutions) face new challenges. In times, when production processes are highly automated the value is found in giving the products and services attributes that are attractive to consumers. Intangible goods so typical to creative economy need to satisfy needs on the highest levels of the Maslov's pyramid. Almost infinite resources of images, music and videos put the internet ecosphere in privileged position over classic cultural and creative institutions with business models relied mostly on ticket sales. Even in case of digitised collections presenting commercial value for museums and galleries, current monetization strategies rely mostly on image licensing for prints. Cultural and Creative institutions are struggling to invent/adapt new business models to recover lost fees in case of even more popular open (royalty free) access to media over the internet. Moreover, the rise of Generation Z (born between 1995 and 2015) and their "native" use of social media since early childhood requires re-thinking of current business models. Two directions of the undergoing change can be observed: diversification of the sources of income 
and more participative approaches to audiences/visitors aimed at reaching a wider audience.

The purpose of the article is to verify how new technology-driven business approaches are perceived by young generation also whether Polish (young) people have similar to global issues. Moreover, the article's aim is to diagnose if they are willing to actively participate in new forms of digital economy. In order to achieve given goals, both literature and empirical studies were conducted. The research results may be helpful to managers (especially in the CCII area) to build and develop business models accelerating convergence of virtual and material spheres.

\section{Business models' overview}

A business model is a concept that has no uniform definition. Several authors dealing with this subject propose their own explanations of this term showing their personal view on how business models should look like. At a general level the business model has been referred to as a statement (Stewart and Zhao, 2000), a description (Applegate, 2000; Applegate, 2001; Weill and Vitale, 2001), a representation (Morris et al., 2005; Shafer et al., 2005), an architecture (DubossonTorbay et al. 2002; Timmers 1998,), a conceptual tool or just a model (Osterwalder et al .2005), a structural template (Amit and Zott, 2001), a method (Afuah and Tucci, 2001), a framework (Afuah, 2004), a pattern (Brousseau and Penard, 2006), and as a set (Seelos and Mai, 2007). Surprisingly, existing definitions only partially overlap, giving rise to a multitude of possible interpretations. Most authors describe business models as sources of revenue including specification of business actors along with a description of the possible benefits they may have and their roles. A business model can also be described as the structure, targeting and content of transactions performed to enable creation of value by exploitation of business opportunities. Other definitions indicate that a business model it is a method of a company operation that provides profits for it. By acting according to its business model, the company will grow and offer customers offer that is better than the competition, while achieving the highest profits. It indicates also, that the business model should answer questions about the scope of the company's operations, its resources, competition and customers. Yip suggested that "a business model embraces the target customer, the nature of the business and how revenues (and hopefully profits) are generated" (Yip, 2004). Combe put stress on various links between stakeholders reflecting their business models (Table 1.) (Combe, 2006). Rappa stated: "a business model is the method of doing 
business by which a company can sustain itself - that is, generate revenue"; the business model spells-out how a company makes money by specifying where it is positioned in the value chain (Rappa 2004). Finally, Mansfield and Fourie proposed that "a business model most commonly describes the linkage between a firm's resources and functions and its environment; it is a contingency model that finds an optimal mode of operation for a specific situation in a specific market" (Mansfield and Fourie 2004). In the context of this article the definition by Afuah and Tucci is adopted. The experts claim that the business model is a method of expanding and using resources adopted by the company in order to provide customers with products and services, the value of which is better than the offer of competition and which at the same time ensures profitability for the company (Afuah and Tucci, 2003). This definition encompasses two fundamental elements on which most of the aforementioned definitions agree, that is, the transformation of resources into value and the extraction of profit from it.

\section{Table 1. Typical classification of business models presented as relations of stakeholders}

\begin{tabular}{l|l|l|l}
\hline & Government & Business & Consumer \\
\hline Government & $\begin{array}{l}\text { G2G } \\
\text { Administration of } \\
\text { Institutions, Digital } \\
\text { Signature, Digitalisation, } \\
\text { Subventions }\end{array}$ & $\begin{array}{l}\text { G2B } \\
\text { Information flow, Support } \\
\text { for R\&D }\end{array}$ & $\begin{array}{l}\text { G2C } \\
\text { Information flow, } \\
\text { Support for social areas }\end{array}$ \\
\hline Business & $\begin{array}{l}\text { B2G } \\
\text { Public procurement }\end{array}$ & $\begin{array}{l}\text { B2B } \\
\text { 'classic' business } \\
\text { (production, trade, services) }\end{array}$ & $\begin{array}{l}\text { B2C } \\
\text { 'Classic' trade, services }\end{array}$ \\
\hline Consumer & $\begin{array}{l}\text { C2G } \\
\text { Taxes, tickets }\end{array}$ & $\begin{array}{l}\text { Price comparators, fan- } \\
\text { pages }\end{array}$ & $\begin{array}{l}\text { C2C } \\
\text { Blockchain, torrents, } \\
\text { auctions, barter } \\
\text { exchange, }\end{array}$ \\
\hline
\end{tabular}

Source: C. Combe, Introduction to e-business, management and strategy, Amsterdam Boston - Heidelberg - London - New York - Oxford - Paris 2006

The definition of the e-business model does not much differ from the above mentioned terms of traditional enterprises. The only difference is the definition of the scope of activity assuming that enterprise is operating in the internet, or, more broadly, using modern ICT technologies (see table 2.). 
Table 2. Selected E-business models (according to some authors)

\begin{tabular}{|c|c|}
\hline Author & Models \\
\hline P. Timmers & $\begin{array}{l}\text { - e-shop, e-mall } \\
\text { - e-procurement } \\
\text { - e-auction } \\
\text { - virtual community } \\
\text { - value-chain integrator } \\
\text { - value-chain service provider } \\
\text { - collaboration platform } \\
\text { - information brokerage } \\
\text { - trust services } \\
\text { - application service provider, ASP }\end{array}$ \\
\hline M. Rappa & $\begin{array}{l}\text { - } \text { brokerage model } \\
\text { - } \text { advertising model } \\
\text { - infomediary model } \\
\text { - } \text { merchant model } \\
\text { - } \text { manufacturer (direct) model } \\
\text { - } \text { affiliate model } \\
\text { - community model } \\
\text { - } \text { subscription model } \\
\text { - utility model }\end{array}$ \\
\hline $\begin{array}{l}\text { P. Weill, } \\
\text { M.R. Vitale }\end{array}$ & $\begin{array}{l}\text { - direct-to-customer } \\
\text { - full-service provider } \\
\text { - virtual community } \\
\text { - content provider } \\
\text { - shared infrastructure } \\
\text { - whole-of-enterprise/government } \\
\text { - value net integrator } \\
\text { - intermediary }\end{array}$ \\
\hline C. Combe & $\begin{array}{l}\text { - brokerage } \\
\text { - e-shops, e-malls } \\
\text { - e-auctions } \\
\text { - trading communities } \\
\text { - virtual communities } \\
\text { - buyer aggregator model } \\
\text { - classifieds } \\
\text { - infomediaries } \\
\text { - e-procurement } \\
\text { - distribution model) } \\
\text { - general portal, personalised portals, vortals } \\
\text { - collaboration platforms } \\
\text { - third-party marketplaces } \\
\text { - value-chain integrator }\end{array}$ \\
\hline
\end{tabular}


- value-chain service provider

- manufacturer model

- affiliate model

- subscription model

- models for mobile wireless technology)

Source: own work based on various references

\section{Demography of Generation Z}

Generation Z (born between 1995 and 2015) is widely considered to be the next big generation. Businesses are therefore struggling to find ways to attract the youngest generation. Internet and social networks are native to Generation Z. Members of that group have other distinctive characteristics such as: 'expertise', 'self-sufficiency', 'abruptness', 'digitality' and JOMO (JoyOf-Missing-Out), and 'loneliness'. Young people are becoming wiser. Internet offers a plethora of sources and inspirations to educate oneself. Social media, Wiki, reviews, forums, tutorials, information portals, on-line courses offer infinite source of information available at hand. This requires companies and institutions to "constantly innovate, drive prices down, streamline and aestheticize their offerings" to stay relevant, in the words of Euromonitor. With open access to any information 'on-demand' Generation $\mathrm{Z}$ assumes that feel they don't have to consult a professional to make decisions regarding their lifestyle, diets, fitness regimes, opinions, interior design and so on (Stankiewicz et al., 2017). Actually, they're getting rid of any brokerage and are accustomed to 'free' open access to information over the Web. In the process of looking after oneself, many young people prefer personalization services to create a unique product and experience that suits their individual preferences. Moreover, they are impatient and have very short attention spans. According to Euromonitor's report members of Generation $Z$ are busy and time is a luxury for them. Many young consumers are looking for "frictionless experiences that mesh with their lifestyles, allowing them to dedicate more time to their professional or social lives". Generation Z wants to go 'back to basics', and admire products and experiences positioned as 'minimalist' and 'crafted' to "sparkle their joy". Speaking of joy, JOMO stands for Joy-Of-Missing-Out and means that young generation is becoming tired of being constantly bombarded with new information and the blurred boundaries between work and personal 
life. Citing Euromonitor, "The fear of being left out is giving place to the reappropriation of self-time" (Euromonitor 2019). It means that young people can appreciate not only online-content but can focus their attention on the surrounding world. It does not mean that Generation $\mathrm{Z}$ rejects internet. They use digital media in 'native' manner (Hallam 2012; Loader et al., 2014). Text and video chatting, real-time collaboration, virtual meetings with participants across the globe, extended reality (Virtual and Augmented Reality) are handful of their daily used 'tools'. More and more people have access to mobile broadband Internet, and the range of things they can do together digitally will grow even more. Experts expect those interactions to become even more lifelike and will be more participative than just 'browsing' the Web. To follow that trend, businesses and institutions are coming up with products and services that are based on artificial intelligence, virtual reality and predictive analytics (Prohm, 2018). Interaction over the Internet means less physical contact with the nearest social circle. Generation $\mathrm{Z}$ is a group of lonely people. The number of single-person households is forecasted to outpace the growth of all other household types, according to a recent study by Pew Research Center (PRC, 2017). Young people are rejecting marriage and cohabitation that will result in more disposable income and attention. Even now we can observe increasing number of young adults using their spare time to travel, study, explore and have fun. It is also expected that Generation $\mathrm{Z}$ will prefer living in denser, perfectly communicated urban settings with various amenities and no need to own a private car (Goh and Lee, 2018).

\section{Research methodology, sample characteristics and preliminary research results}

The aim of the study was to identify differences/similarity in perception, acceptance and willingness to participate in digital economy associated with Creative Cultural Institutions among the representatives of young (particularly Z) generations. It was conducted in the 2018 by means of direct survey technique, using a categorized and standardized questionnaire. A decision was made to perform a deliberate than random sample selection. The research was a pilot/preliminary study (as a Proof of Concept) to provide an introduction to the broader studies on Polish Generation $\mathrm{Z}$ participation in digital technology driven CCII. Eight questions were asked, including sociodemographic variables. During the research, the opinions of 50 specifically selected respondents- residents of Lubuskie Province -were analysed. 10\% 
were teenagers (below 18 years old), 56\% were in the 18-26 age range, 34\% were 27 and older. There were equal gender participation 50\% men 50\% women.

The research shows the involvement of younger generation in digital business. One of the questions was considering technology maturity and potential problems with persistent internet, smartphones and mobile computing. $96 \%$ of respondents confirmed no problems and intuitive use of the digital technology. $84 \%$ of respondents agreed that development of ICT technology in the last 10 years was tremendous, 16\% thought it was at normal pace. Similar result was obtained with query on how digital technology influence the business/work areas. Over $84 \%$ of respondents declared it to be very high. Participants in the research were afraid of potential issues and risk of job loss caused by digital automation, $60 \%$ thought it could happen to them, $35 \%$ thought the risk was low while only $5 \%$ couldn't declare their opinion. Almost $50 \%$ of respondents admitted that blurred border between work and personal life time is stressful and can cause insomnia, making JOMO more and more attractive to the population. The research demonstrated that $78 \%$ of the respondents valued easy access to digital information and declared it to be their daily used 'tools'. As far as e-business was considered, 18\% understood it as running business in the Internet, $42 \%$ chosen $24 / 7$ access to online business, $30 \%$ thought of e-commerce and 10\% valued instant access to any (business) information. Digital CCII was clearly recognized by the responders, new IPR (Intellectual Property Rights) business and jobs such as freelance graphic design, translation services, copywriters, online marketing services gathered $50 \%$ of the poll, the remaining $50 \%$ was representative to the older responders, accustomed to more traditional business/job models.

Summing up, the understanding and openness of the surveyed participants to digital technology and e-business is well established and for younger generation there is almost no difference between global Generation $Z$ and their Polish representatives. Surprisingly, all responders use ICT in highly 'native' manner and on a daily basis and require institutions to be at similar level of digital technology maturity.

\section{Managing Generation Z - case studies of new CCII business models handling internet and social networks}

Against recent technological developments, the traditional cultural and creative institutions business models appear very static: captive audiences 
watch a relatively small selection of content/collection and have little choice or flexibility in what they watch or when. The audience is very passive and is not allowed to interactively interfere the artwork. Considering the Combe model depicted in Table 1. art galleries, museums, theatres and concert halls act mostly on G2G ground, where most of the institution budget is covered by different forms of subventions. $\mathrm{C} 2 \mathrm{G}$ model incorporates ticket sales (they are also subject to subventions for different demographic groups of audience). E-business (see Table 2) in such cases is usually limited to on-line information on exhibit, repertoire and sometimes online ticket sales. The museums and art galleries with digitized collections can benefit from monetization of copyrights, however some of them are accused of acting against academic projects because of a "tax on scholarship". The Tate and the British Museum are among institutions that charge scholars to reprint historic artworks in journals, books and lectures (The Times, 2017).

Emergence of the open access model of information sharing in the internet requires different approaches. The Rijksmueum the OpenGLAM movement in 2011, releasing to the public domain images of artworks in its collection (Verwayen et al., 2011). Some studies have demonstrated that OpenGLAM provides various benefits to museums and art galleries, ranging from the wider dissemination of their collections (also among younger audience) to increased sponsorship opportunities (Kapsalis, 2016). In the wider perspective, the movement's adoption remains still very limited. One of the barriers for joining OpenGLAM is the "fear of losing image licensing revenue", as participant museums and art galleries have use alternative new business models to recover lost copyright fees (Sanderhoff, 2013). Among current efforts to address this challenge Print-onDemand services are introduced for creating and purchasing products featuring the galleries and museum's artworks (Gorgels, 2013; Simal, 2005). A different approach that integrates Print-on-Demand automation with currently available ICT technologies (including image recognition and progressive web applications) to generate revenue from digitisation is the Infinite Museum Store (IMS) (Valeonti et al., 2018).

Digital nation as sometimes Generation $\mathrm{Z}$ is referred, prefer personalization services to create a unique product and experience that suits their individual preferences that are more participative than just 'browsing' the Web. To satisfy these demands, some cultural institutions are coming up with products and services that are based on artificial intelligence. AI based experiences guide our thinking on how the knowledge-set and intelligence inherent in an image, text or data set can be exploited to access information in a form and style embodying 
the 'character' of a person, matching them as some adequate or plausible the observer. The example of the science museum in Milan that 'programmed' Da Vinci as a chatbot is very informative. In that project, an avatar of Da Vinci could only come off as dumb when it sought to resemble Da Vinci the historical person, whereas as a cartoony mascot figure performing a limited but plausible interactivity was perceived as effectively intelligent and "Da Vinci-like" in spirit (Boiano et al. 2003). Humboldt's effort to bring Wilhelm and Alexander to digital life as artificial intelligences one day is a way to broaden the museum experience (Prohm 2018).

The integration of social media into one's daily life is assumed to be the most distinct demographic features of Generation Z. For museums, galleries and other cultural institutions in order to engage with this audience group efficiently, their exhibitions have to take social media into the consideration of business strategies.

Engagement Process with stages including Attractor, Sustainer and Relator can be used to introduce social media concepts to curator's strategies (Edmonts et al., 2006). Based on the study on visitor behaviour and usage models within the museum space this Engagement Process includes three stages. The first one is the Attractor, with attributes aiming to grab people's attention that encourage the audience to start the experience. The second stage is the Sustainer that hold the audience engaged throughout the process. They carry "holding power" to sustain the audience's interest, generating exhibition hotspots where the audience stays and interacts with the exhibition. The last one is the Relator that comment the exhibition during and after the experience (Bollo and Dal Pozzolo, 2005). The exhibition One World Exposition 2.1: \#like4like employed such curatorial strategies to intentionally manipulate audience behaviour (Chung, 2018). It proved to be generally successful in activating audience participation on social media.

The audience response to the exhibitions on social media directly reflected the level of effectiveness of mediating exhibition context via audience participation on social media. For instance, selfie-taking behaviour yielded a by-product of the exhibition, the photo image, that served as triggering materials for potential online distribution on social media (ccaixiaozhu, 2017). Another implication observed from the social media presence of the exhibition is that social media celebrities are a significant stakeholder in this mode of engagement. They play a major role in distributing information on social media behaviour making their followers want to visit the exhibition personally (Chung, 2018). 
Interaction with the exhibition is the key aspect of Generation Z. Cultural institutions practice should combine media art with socially relevant advocacy. The Art is a powerful tool to reach different audiences, to invite participation thanks to the powerful amplification tools of digital media (Museum4Punkt0, 2018). There are more and more illustrations of successful implementation of digital content in the offer of cultural institutions (Rennick-Egglestoneet al., 2016). The Digitopia Interactive was designed for children and adults of families, and also individual users, e.g. adults without families, and social groups, e.g. large birthday parties (Schnaedelbach et al., 2018). Digital technologies such as Virtual Reality and Augmented Reality were also used for sharing quality time between family members or a group of young people. Spatial Augmented Reality (SAR) technologies can address a more socially and bodily engaging experience for the group members. It gave visitors the impression of interacting with 3D animated models of a shark and a group of penguins (Mazedia, 2018).

\section{Conclusion}

CCII (Cultural and Creative Industries and Institutions) can take advantage over the digital economy. More and more functions of associated business move to cyberspace. It requires, however, profound understanding of new business models in digital economy. Art and culture with its plethora of intangible goods can satisfy needs not only of connoisseurs but wider and younger audiences. Infinite resources of images, music and videos put the internet ecosphere in privileged position over classic cultural and creative institutions with business models relied mostly on ticket sales and G2G financial support. Cultural institutions does not have to struggle to invent/ adapt new business models to recover lost fees in case of even more popular open (royalty free) access to media over the internet. They can follow the rise of Generation Z and their "native" use of social media since early childhood to change their business models ad adapt to XXI century. Equipped with personalized content and based on high digital literacy both workforce and customers can lead to modern CCII solutions. Being the subject of digital transformation, all generations (including the young Poles) can have mutual benefits from successive technologies leading to maximization of broadly understood advantages. The Holy Grail of digital economy can be found in appropriate reaction to engagement of users, virtualisation of data, technology, creativity and managerial efficiency. 


\section{Summary}

\section{New business models for Cultural Institutions}

Total integration of social media and internet into daily life of the young people is the most distinct demographic characteristics of the Generation Z (born between 1995 and 2015). For Cultural and Creative Industries and Institutions in order to engage with this audience efficiently, their business models have to consider social media and more participative approach. The paper addresses the challenges and opportunities that face cultural institutions by analysing and assessing the business models related to new internet solutions. The paper provides a fresh review of the business models in which the author examines the new business model concepts through CCII subject-matter lenses. Discussed casestudies show generally successful result in activating Generation $\mathrm{Z}$ audience participation in cultural activities. While trying to understand limitations of the cultural institutions position and motivation towards social media and generally mobile internet, the paper raises critical implications of the pervasive internet in the CCII area.

Keywords: Business Administration, Management, and Operations, CCII, Business Models.

\section{Streszczenie}

\section{Nowe modele biznesowe dla instytucji kultury}

Całkowita integracja mediów społecznościowych i Internetu w codziennym życiu młodych ludzi jest najbardziej wyraźną cechą demograficzną charakteryzującą Generację Z (urodzoną w latach 1995-2015). W przypadku instytucji kultury i przemysłów kreatywnych CCII (ang. Cultural and Creative Industries and Institutions), aby skutecznie dotrzeć do tej publiczności, modele biznesowe ich działań muszą uwzględniać media społecznościowe i bardziej partycypacyjne podejście do widza. Niniejszy artykuł dotyczy wyzwań oraz możliwości stojących przed instytucjami kultury CCII przedstawiając analizę i ocenę modeli biznesowych związanych z nowymi rozwiązaniami internetowymi. Artykuł przedstawia przegląd modeli biznesowych, w których autor analizuje proponowane rozwiązania $\mathrm{z}$ perspektywy 
wykorzystania nowych modeli $\mathrm{w}$ obszarze CCII. Omówione przypadki pokazują ogólnie pozytywny efekt aktywizacji uczestnictwa Generacji Z w odbiorze i działaniach kulturowych. Niniejsze opracowanie ma na celu wywołać dyskusję nad krytyczne implikacje wszechobecnego Internetu w obszarze CCII.

\section{Słowa}

kluczowe: Administracja, zarzadzanie i biznes, instytucje kultury i przemysty kreatywne, modele biznesowe.

\section{JEL}

\section{Classification: M31}

\section{References}

1. Afuah, A., \& Tucci, C. L. (2003). Internet business models and strategies: Text and cases (2nd ed.). Boston: McGraw-Hill.

2. Afuah, A. (2004). Business models: A strategic management approach. New York: Irwin/McGraw Hill.

3. Amit, R., Zott, C. (2001). Value creation in e-business. Strategic Management Journal, 22: pp. 493-520.

4. Applegate, L. M. (2000). E-business models: Making sense of theinternet business landscape. In G. Dickson \& G. DeSanctis (Eds.), Information technology and the future enterprise: New models for managers: 49-101. Englewood Cliffs, NJ: Prentice-Hall.

5. Applegate, L. M. (2001). Emerging e-business models: Lessons from the field. HBS No. 9-801-172, Harvard Business School, Boston, MA.

6. Boiano, Stefania; Gaia, Giuliano; Caldarini, M. (2003). "Make Your Museum Talk: Natural Language Interfaces For Cultural Institutions" conference paper in Museums and the Web 2003, Toronto, CA, 20-22 March 2003

7. Bollo, A. Dal Pozzolo, L. (2005). Analysis of visitor behaviour inside the museum: An empirical study. Proceedings of the 8th International Conference on Arts and Cultural Management, Montreal, vol. 2, pp. 113.

8. Brousseau, E., \&Penard, T. (2006). The economics of digital business models: A framework for analyzing the economics of platforms. Review of Network Economics, 6(2):pp. 81-110.

9. ccaixiaozhu (2017): Videotage on Instagram: “[\#videotagelike4like] no Face, no Identity, no Sound, no Language, no Subtitle, no Narration, no Context, Only Ambiguous..." , Available from: https://www.instagram. $\mathrm{com} / \mathrm{p} / \mathrm{BUO}-7 \mathrm{nlB} 61 \mathrm{D} /(29.01 .2109$ - access date)

10. Chung, K. (2018). Mediating Exhibitions via Audience Participation on Social Media: Collectivist Curatorial Approach in One World Exposition 2.1 Exhibition 
Proceedings of the EVA Berlin 2018 Conference, Berlin, 8-10 November 2018, pp. 151-159

11. Combe, C. (2006). Introduction to e-business, management and strategy, Amsterdam - Boston - Heidelberg - Londyn - NowyJork - Oxford - Paryż.

12. Dubosson-Torbay, M., Osterwalder, A., \&Pigneur, Y. (2002). E-business model design, classification, and measurements. Thunderbird International Business Review, 44(1): pp. 5-23.

13. Edmonds, E., Muller, L.,Connell, M. (2006). On Creative Engagement. Visual Communication, vol. 5, no. 3, pp. 307-322.

14. Euromonitor report. https://go.euromonitor.com/white-paper-EC-2019Top-10-Global-Consumer-Trends.html (29.01.2109 - access date)

15. Goh, E. \& Lee, C. (2018). A Workforce to be Reckoned with: The Emerging Pivotal Generation Z Hospitality Workforce. International Journal of Hospitality Management, vol. 73, pp. 20-28.

16. Gorgels P. (2013): P. Gorgels, Rijksstudio: Make Your Own Masterpiece!. In Museums and the Web 2013, N. Proctor \& R. Cherry (eds). Silver Spring, MD: Museums and the Web.

17. Hallam, J.(2012). The Social Media Manifesto, Palgrave Macmillan, London.

18. Kapsalis, E. (2016). The Impact of Open Access on Galleries, Libraries, Museums, $\mathcal{E}$ Archives Smithsonian Emerging Leaders Development Program.

19. Loader, B., Vromen, A. \&Xenos, M. A. (2014). The Networked Young Citizen: Social Media, Political Participation and Civic Engagement, Routledge, New York.

20. Mansfield, G. M., \& Fourie, L. C. H. (2004). Strategy and business models: Strange bedfellows? A case for convergence and its evolution into strategic architecture. South African Journal of Business Management, 33(1), pp. 35-44

21. Mazediahttps://www.mazedia.fr/(29.01.2109 - access date)

22. Morris, M., Schindehutte, M., Allen, J. (2005). The entrepreneur's business model: Toward a unified perspective. Journal of Business Research, 58: pp. 726-35.

23. Museum4Punkt0 https://www.museum4punkt0.de/en/(29.01.2109 access date)

24. Osterwalder, A., Pigneur, Y., Tucci, C. L. (2005). Clarifying business models: Origins, present and future of the concept. Communications of the Association for Information Science (CAIS), 16: pp. 1-25.

25. Pew Research Center (2017). http://www.pewresearch.org/facttank/2017/10/11/the-share-of-americans-living-without-a-partner-hasincreased-especially-among-young-adults/ (29.01.2109 - access date)

26. ProhmA. (2018). Double Humboldt:Thoughts on the Digital Twinning of the Humboldt Brothers, Proceedings of the EVA Berlin 2018 Conference, Berlin, 8-10 November 2018, pp. 137-146.

27. Rappa, M. (2004). Business models on the Web. Retrieved February 9, 2007, from http://digitalenterprise.org/models/models.html (29.01.2109 access date) 
28. Rennick-Egglestone, S., et Al.(2016). Families and Mobile Devices in Museums: Designing for Integrated Experiences. J. Comput. Cult. Herit. 9(2): p. 1-13.

29. Sanderhoff, M. (2013). Open Images. Risk or opportunity for art collections in the digital age? Nordisk Museologi, (2), pp. 131-146.

30. Seelos, C., Mair, J. (2007). Profitable business models and market creation in the context of deep poverty: A strategic view. Academy of Management Perspectives, 21: pp. 49-63.

31. Shafer, S. M., Smith, H. J., Linder, J. 2005. The power of business models. Business Horizons, 48: pp. 199-207.

32. Schnaedelbach, H. et Al. (2018). DIGITOPIA: An Interactive Experience to Accompany a Dance Performance for Families, Proceedings of the EVA Berlin 2018 Conference, Berlin, 8-10 November 2018, pp. 127-136.

33. Simal, J. (2005). On-Demand Printing Transforming Museum Visitors Experience. DPP2005: IS\&T's International Conference on Digital Production Printing and Industrial Applications, Amsterdam, pp. 141-142.

34. Stankiewicz, J., Seiler, B., Bortnowska, H. (2017). Young people as a subject of human resources management in the third sector organizations, Management 2/2017, pp. 68-80.

35. Stewart, D. W., Zhao, Q. (2000). Internet marketing, business models and public policy. Journal of Public Policy and Marketing, 19: pp. 287-296.

36. The Times (2017) https:/ / www.thetimes.co.uk/article/museum-fees-arekilling-art-history-say-academics-qhfwmdws6 (29.01.2109 - access date)

37. Timmers, P. (1998). Business models for electronic markets. Electronic Markets, 8(2):pp. 3-8.

38. Valeonti, F., Hudson-Smith, A., Terras, M., Zarkali, C. (2018): Reaping the Benefits of Digitisation: Pilot study exploring revenue generation from digitised collections through technological innovation. Proceeding of EVA London 2018, London, UK, 9-12 July 2018, BCS Learning and Development Limited, pp. 56-63.

39. Verwayen, H., Arnoldus, M., Kaufman P. (2011). The Problem of the Yellow Milkmaid, Europeana Whitepaper No.2.

40. Weill, P., Vitale, M. R. (2001). Place to space: Migrating to e-business models. Boston, MA: Harvard Business School Press.

41. Yip, G. S. (2004). Using strategy to change your business model. Business Strategy Review, 15(15), 17-24.

42. Zott, C., Amit, R. (2009). The business model as the engine of network-based strategies. In P. R. Kleindorfer\& Y. J Wind (Eds.), The network challenge. Upper Saddle River, NJ: Wharton School Publishing. pp. 259-275. 